УДК 37.013:004.378.147.811

Чаюк Тетяна Андріївна

кандидат філологічних наук, викладач кафедри іноземних мов юридичного факультету

Київський національний університет імені Тараса Шевченка, м. Київ, Україна

ORCID ID 0000-0001-5318-688X

chajuk.t@gmail.com

\title{
ОНЛАЙН ІНСТРУМЕНТИ ДЛЯ ОЦІНЮВАННЯ ІНШОМОВНОЇ КОМПЕТЕНТНОСТІ СТУДЕНТІВ ВИЩИХ ЗАКЛАДІВ ОСВІТИ: ЗАРУБІЖНИЙ ДОСВІД
}

\begin{abstract}
Анотація. У статті висвітлено проблеми формування та оцінювання іншомовної компетентності студентів вищих навчальних закладів; надано результати аналізу та характеристика основних міжнародних онлайн тестів для об'єктивного оцінювання рівня володіння англійською мовою студентами закладів вищої освіти. Такі тести можуть забезпечувати їхне самонавчання та самооцінювання. Відтворено структури міжнародних онлайн тестів із англійської мови як іноземної та наведені приклади тестових завдань. Виокремлено, проаналізовано та схарактеризовано основні міжнародні онлайн тести для об'єктивного оцінювання рівня володіння англійською мовою студентами закладів вищої освіти. Виокремлено, проаналізовано та схарактеризовано основні міжнародні онлайн тести, що можуть забезпечувати самонавчання та самооцінювання, для об'єктивного оцінювання рівня володіння англійською мовою студентами закладів вищої освіти, а саме: тести Кембриджської шкали оцінки професійних компетентностей викладачів іноземної мови; тести Кембриджського екзамену, що містить у собі такі тести, як Ключовий тест 3 англійської мови; Попередній тест 3 англійської мови; Перший сертифікат 3 англійської мови; Сертифікат із прогресивним рівнем володіння англійською мовою; Сертифікат із майстерним рівнем володіння англійською мовою; Інтернет орієнтований тест з англійської мови як іноземної та Міжнародна тестова системи англійської мови. Аналіз цих тестів показав, що вони, загалом, складаються з чотирьох частин, таких як читання, слухання, говоріння, письмо, та базуються на Загальноєвропейських рекомендаціях з мовної освіти: вивчення, викладання, оцінювання. Ці тести $є$ зручним інструментом у процесах викладання англійської мови та навчання мові, оскільки забезпечують такі функції: викладачеві - зручну швидку перевірку рівня володіння студентом англійською мовою, можливість переглянути типові помилки та обговорити їх зі студентами для корегування їхнього подальшого плану навчання, можливість підвищити рівень викладання іноземної мови завдяки використанню онлайн тестів; студенту - можливості неперервного навчання англійській мові та постійного підвищення свого рівня володіння мовою для отримання в подальшому необхідного сертифіката. Перспективами подальших досліджень $\epsilon$ впровадження міжнародних онлайн тестів в освітній процес закладу вищої освіти для проведення оцінювання рівня володіння англійською мовою та аналіз впливу цих інструментів на рівень іншомовної компетентності студентів.
\end{abstract}

Ключові слова: онлайн оцінювання; онлайн тест; іншомовна компетентність; заклад вищої освіти.

\section{1. ВСТУП}

Знання іноземних мов $є$ однією 3 основних умов становлення та розвитку особистості суспільства XXI століття, що пояснюється світовими тенденціями щодо вдосконалення освіти і науки, передусім такими, як впровадження компетентнісного підходу в освіті та існування особливих вимог до фахівця на світовому ринку праці [1].

Так, однією з ключових компетентностей особистості відповідно до Рекомендацій Європейського Парламенту та Ради Європейського Союзу (ЄС) «Про основні компетентності для навчання протягом усього життя» від 18 грудня 2006 року [2] $\epsilon$ 
спілкування іноземними мовами (англ. communicating in a foreign language), що має бути головним чинником для забезпечення і здійснення, насамперед, академічної мобільності молоді в науковому просторі та іiї конкурентоспроможності у світі.

Постановка проблеми. Важливої ролі набуває оцінювання іншомовної компетентності студентів закладів вищої освіти (3ВО) для створення та корегування курсів іноземної мови згідно зі світовими стандартами володіння іноземними мовами, зокрема англійською як іноземною. 3 цього приводу однією з актуальних форм такого оцінювання $є$ онлайн-формат. Це пояснюється його впливом на мотивацію студентів проходити онлайн-тести через швидкий зворотний зв'язок та максимальне об'єктивне оцінювання результатів, що дозволяє викладачу значно скоротити витрати часу на здійснення контролю і позбавити його трудомісткої роботи під час обробки результатів тестування [3].

Аналіз останніх досліджень і публікацій. Проблеми формування та оцінювання іншомовної компетентності студентів вищих навчальних закладів розглядались у роботах вітчизняних дослідників Булахової Я. В. (інженерів-програмистів, 2007); Демченко Д. І. (майбутніх юристів, 2010); Нітенко О. В. (фахівців із права, 2015), Опрятного С. М. (державних службовців, 2005); Хоменко О. В. (студентів економічних спеціальностей, 2015) та ін., зарубіжних учених Lasagabaster, D. (2008), Drury, H., Dunworth, K., Kralik, C., Moore, T., Mulligan, D. (2012) та ін.

Термін «іншомовна комунікативна компетентність» ученими трактується як застосування знань, умінь та навичок, необхідних для розуміння чужих і власних програм мовленнєвої поведінки, адекватних цілям, сферам, ситуаціям спілкування, зміст яких охоплює знання основних понять лінгвістики мови (стилі, типи, способи зв'язку речень у тексті), навички та вміння аналізу тексту і власні комунікативні надбання - знання мови, високий рівень практичного володіння як вербальними, так i невербальними іiі засобами, а також досвід володіння мовою на варіативноадаптивному рівні залежно від конкретної мовленнєвої ситуації [3]; [4]; [5]; [6]. Іншомовні комунікативні знання, уміння та навички належать до інструментальних компетентностей і відіграють особливу роль у забезпеченні ефективного спілкування сучасних здобувачів усіх освітньо-кваліфікаційних рівнів [4].

Для ефективного проведення оцінювання іншомовної комунікативної компетентності вітчизняні та зарубіжні вчені (Нікітіна Н. С. [7], Ніколаєва С. Ю. [6], Clarke, C. M., Garrett, M. F. (2004) [8], Pinto-Llorente, A. M., Sánchez-Gómez, M. C., García-Peñalvo, F. J., Casillas Martín, S. (2016) [9] та ін.) виокремлюють, як один із зручних інструментів, онлайн тест.

Ряд закордонних науковців [9] після проведення експериментального дослідження, яке полягало в аналізі впливу онлайн тестування на рівень володіння студентами англійською мовою як іноземною, з'ясували, що використання онлайн тестів для контролю знань викладачем та самостійного оцінювання рівня володіння англійською мовою студентами забезпечує вдосконалення їхніх знань 3 граматики і лексики, покращення навичок володіння письмом, та надає студентам можливість відчути швидкий зворотний зв'язок, що позитивно впливає на їхню мотивацію проходити онлайн тести та вивчати іноземну мову, допомагає підтримувати i направляти автономне навчання.

Метою статті $\epsilon$ аналіз та характеристика основних міжнародних онлайн-тестів, що можуть забезпечувати самонавчання та самооцінювання, для оцінювання рівня володіння англійською мовою студентів 3ВО. 


\section{2. РЕЗУЛЬТАТИ ДОСЛІДЖЕННЯ}

Виклад основного матеріалу. Слід зазначити, що оцінювання рівня володіння англійською мовою особистістю в міжнародному просторі відбувається згідно 3 рекомендаціями Ради ЄС «Загальноєвропейські рекомендації з мовної освіти: вивчення, викладання, оцінювання» (англ. Common European Framework of Reference for Languages: Learning, teaching, assessment, CEFRL) [10]. У Рекомендаціях пропонуються три категорії (A, B, C), у кожній з яких описуються два рівні володіння іноземною мовою (A1, A2; В1, В2, C1, С2). У кожній категорії надається характеристика таким видам мовленнєвої діяльності, як слухання (аудіювання), читання, писання, говоріння (спілкування). До кожного 3 зазначених рівнів $\epsilon$ обов'язковою оцінка володіння особистістю лексикою (англ. vocabulary control), фонетикою (англ. phonological control), орфографією (англ. orthographic control), граматикою (англ. grammatical control) мови.

Надамо загальні характеристики основних рівнів категорій володіння іноземною мовою особистістю відповідно до Загальноєвропейських Рекомендацій з мовної освіти.

Категорія А містить такі рівні:

- A1 - базовий (англ. Breakthrough - прорив), що свідчить про початковий рівень володіння особистістю мовою, при якому людина може спілкуватись, якщо носій мови говорить повільно і чітко та готовий допомогти;

- A2 - соціалізований (англ. Waystage - етап шляху), що означає передпороговий рівень, при якому людина може розуміти питання, пропозиції та часто використовувані вирази, пов'язані з актуальними галузями соціального життя (наприклад, відомості особистого характеру, відвідування магазинів, місцева географія, зайнятість та ін.).

Категорія В охоплює рівні:

- B1 - пороговий рівень (англ. Threshold - поріг), при якому особистість здатна вирішувати проблеми, що виникають під час подорожі в тій місцевості, де ця мова $\epsilon$ розмовною, побудувати логічний текст на теми, які пов'язані 3 особистими інтересами, описати свої мрії, надії, події особистого життя, досвід, амбіції та коротко пояснити думки і плани;

- В2 - пороговий просунутий рівень (англ. Vantage - перевага), який свідчить про те, що особистість розуміє як конкретні, так і абстрактні основні ідеї складного тексту, який містить наукові дискусії у своїй галузі спеціалізації, може створювати чіткий, детальний текст 3 широкого кола питань i пояснювати власну точку зору щодо актуальних питань та ін.

Категорія $\mathrm{C}$ - це вільне володіння іноземною мовою, що охоплює:

- С1 - рівень професійного володіння (англ. Effective Operational Proficiency ефективний досвід роботи), що свідчить про гнучке та ефективне використання мови особистістю для соціальних, академічних і професійних цілей;

- C2 - досконалий рівень володіння мовою (англ. Mastery - майстерність), який засвідчує, що людина розуміє тексти різних стилів і різних галузей наук, освіти та ін.; вільно читає і пише, робить висновки; швидко і точно висловлює свою думку.

Так, відповідно до цих категорій щодо володіння іноземною мовою, зокрема англійською, існують міжнародні тести щодо оцінювання знань англійської мови, які розроблені такими професійними об'єднаннями як Кембриджська шкала оцінки професійних компетентностей викладача іноземної мови (англ. Cambridge English Teaching Framework, CETF), Європейська рамка кваліфікацій (англ. The European Profiling Grid, EPG), Британська Рада (англ. The Teaching English Continuing Professional 
Development (CPD) Framework (British Council, ELTCPD), Національна Рада 3 професійних стандартів викладання - некомерційне об'єднання професійних педагогів США (англ. National Board for Professional Teaching Standards, NBPTS), міжнародна Асоціація викладачів англійської мови (англ. International Association of Teachers of English as a Foreign Language, IATEFL), австралійська Асоціація 3 викладання англійської мови (англ. Australian Association for the Teaching of English, AATE), Освітня служба тестування (англ. Educational Testing Service, ETS), Міжнародна програма розвитку освіти (англ. International Development Program Education, IDP Education).

Розглянемо докладніше запропоновані вище зазначеними професійними об’єднаннями онлайн тести, які, забезпечуючи насамперед оцінювання рівня володіння особистістю англійською мовою, $\epsilon$ водночас свого роду «тренажерами» для відпрацювання нею практичних навичок застосування англійської мови в різних ситуаціях.

Так, Кембриджська шкала оцінки професійних компетентностей викладачів іноземної мови (англ. Cambridge English Teaching Framework, CETF), що була розроблена у 2014 році Департаментом екзаменів Кембріджського Університету (англ. Cambridge English Language Assessment) [11], охоплює чотири етапи розвитку педагогічної компетентності та п'ять категорій знань та навичок (рис.1).

\begin{tabular}{|l|l|}
\hline \begin{tabular}{l} 
Cambridge English Teaching Framework \\
\hline Teaching English
\end{tabular} & Cambridge English Teaching Framework \\
\hline $\begin{array}{l}\text { Resources for teachers } \\
\text { Cambridge English } \\
\text { Teaching Framework }\end{array}$ & $\begin{array}{l}\text { See where you are in your development - and think about where you want to go next - with the Cambridge } \\
\text { Englishing Framework. }\end{array}$ \\
$\begin{array}{l}\text { Learning and the learner } \\
\text { Ieaching, learning and } \\
\text { assessment }\end{array}$ & $\begin{array}{l}\text { categories of teaching knowledge and skills. Each category describes the key competencies for effective } \\
\text { teaching at each stage. }\end{array}$ \\
\hline $\begin{array}{l}\text { Language ability } \\
\text { Language knowledge and } \\
\text { awareness }\end{array}$ & + Learning and the Learner \\
$\begin{array}{l}\text { Professional } \\
\text { development and values }\end{array}$ & $+\underline{\text { Teaching, Learning and Assessment }}$ \\
$\begin{array}{l}\text { Cambridge English Trainer } \\
\text { Framework }\end{array}$ & $+\underline{\text { Language Ability. }}$ \\
\hline $\begin{array}{l}\text { Teaching qualifications and } \\
\text { courses }\end{array}$ & $+\underline{\text { Language Knowledge and Awareness }}$ \\
\hline
\end{tabular}

Рис.1. Фрагмент сторінки сайту Кембриджської шкали оиінки професійних компетентностей викладачів іноземної мови

На рисунку 1 зображений фрагмент сторінки сайту Кембриджської шкали оцінки професійних компетентностей викладачів іноземної мови, де можна ознайомитися 3 рамкою оцінювання педагогічної компетентності вчителів іноземної мови за такими категоріями: Навчання та учень (англ. Learning and the Learner), Викладання, навчання та оцінювання (англ. Teaching, Learning and Assessment), Мовна здатність (англ. Language Ability), Знання мови та усвідомлення (англ. Language Knowledge and Awareness), Професійний розвиток та цінності (англ. Professional Development and Values).

Кожна категорія описує ключові компетентності для ефективного викладання на кожному з чотирьох етапів розвитку педагогічної компетентності, а саме: базовий (англ. Foundation), розвинутий (англ. Developing), досвідчений (англ. Proficient), експерт (англ. Expert). 
Відповідно до зазначеної вище рамки, студент (майбутній учитель англійської мови як іноземної) може пройти онлайн тести на володіння англійською мовою відповідно до Загальноєвропейських рекомендацій з мовної освіти (рис. 2).

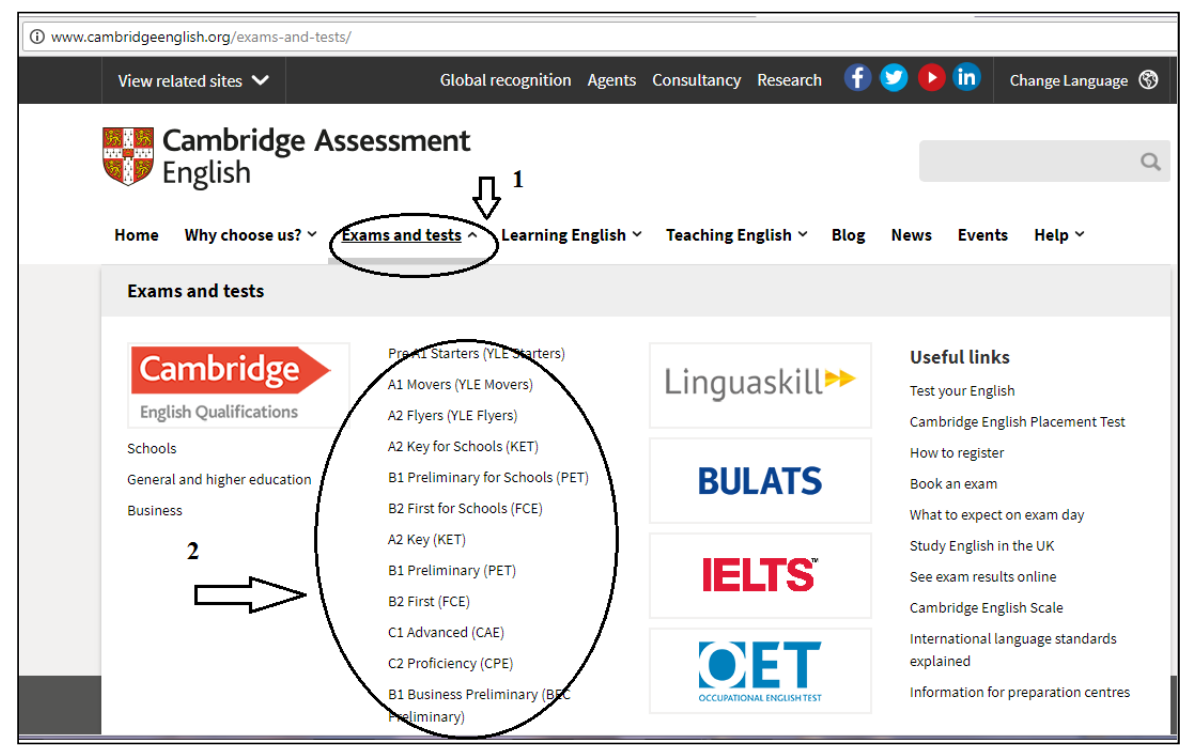

Рис.2. Фрагмент сторінки сайту Кембриджської шкали оцінки професійних компетентностей викладачів іноземної мови, де пропонуються тести з англійської мови для вчителів/майбутніх учителів англійської мови як іноземної, згідно з Загальноєвропейськими Рекомендаціями з мовної освіти

На рисунку 2 надається фрагмент сторінки сайту, де пропонуються тести 3 англійської мови для вчителів/майбутніх учителів англійської мови як іноземної, згідно 3 Загальноєвропейськими Рекомендаціями з мовної освіти та нумерація дій, які має зробити студент для того, щоб розпочати перевірку своїх знань, а саме: 1 - це вхід на сторінку, де розміщені посилання на тести; 2 - посилання на тести.

На рисунку 3 - фрагмент сторінки сайту Кембриджської шкали оцінки професійних компетентностей викладачів іноземної мови, на якій можна вибрати конкретну сферу для проходження онлайн-тесту для тренування.

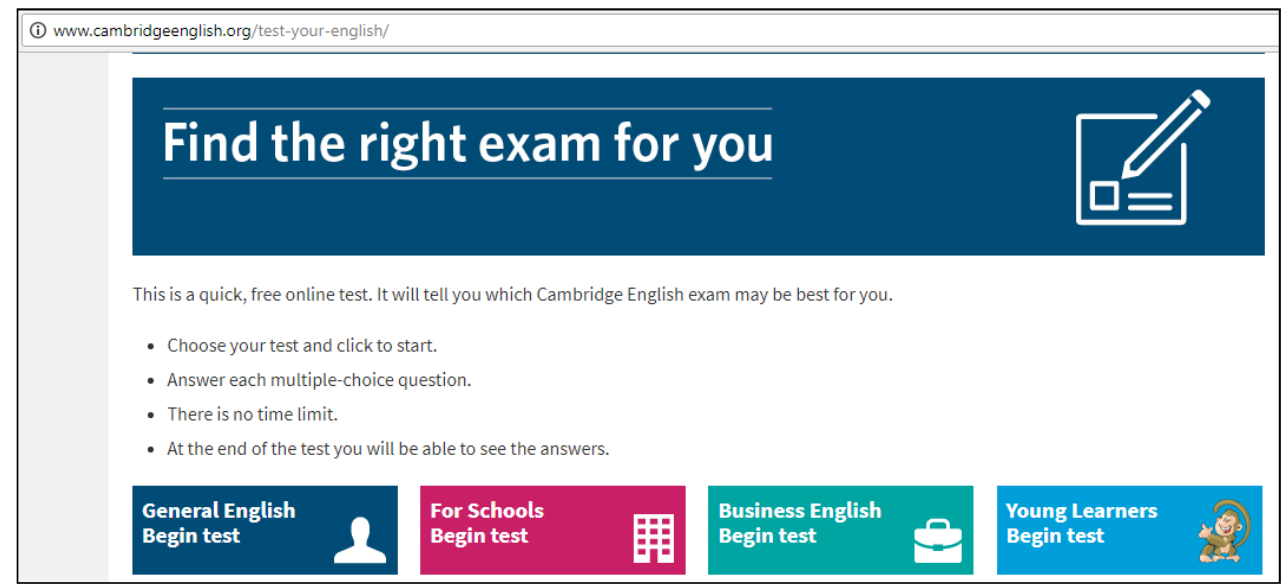

Рис.3. Фрагменту сторінки сайту Кембриджської шкали оичінки професійних компетентностей викладачів іноземної мови, на якій можна вибрати конкретну сферу для проходження онлайн-тесту для тренування 
На рисунку 3 надається фрагмент сайту, де можна вибрати тест для перевірки рівня володіння англійською мовою чотирьох категорій: початковий загальний тест 3 англійської мови (англ. General English Begin test), шкільний початковий рівень (англ. For Schools Begin test), ділова англійська мова (англ. Business English Begin test), початковий тест для дітей (англ. Young Learners Begin test).

Наприклад, тест «For Schools Begin test» містить завдання двох типів, а саме: вибір однісї відповіді на питання (рис. 4) та вибір слова або словосполучення для відтворення речення (рис. 5). Тому, хто проходить тест, слід відповісти на всі задані питання на сторінках, що пропонуються в межах тесту (п'ять питань на п'яти сторінках).

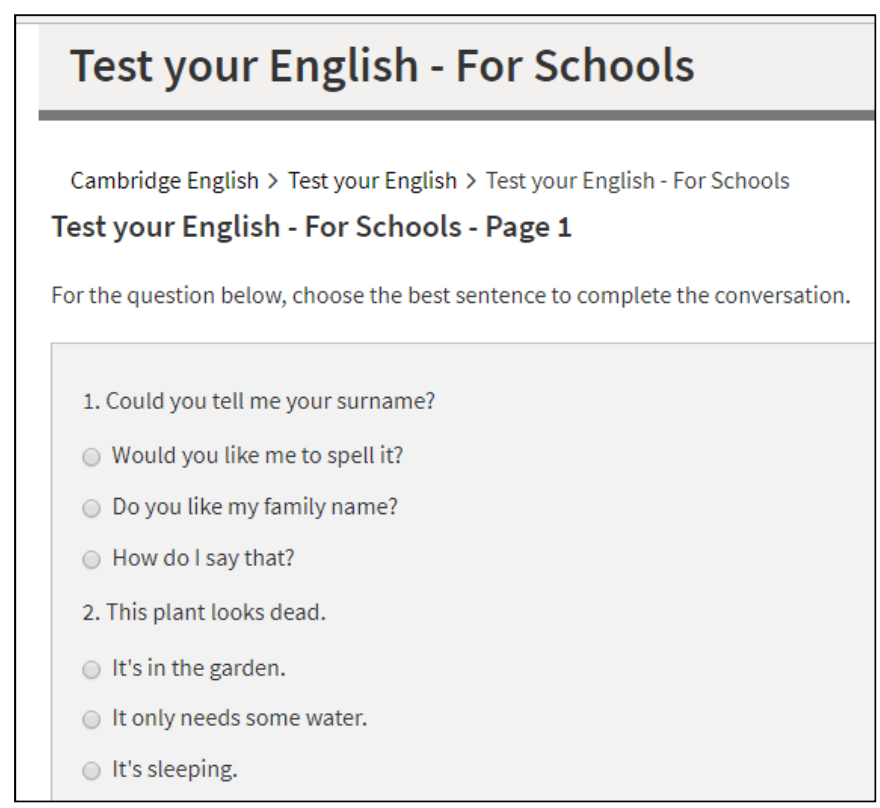

Рис. 4. Приклад тестового завдання типу «вибір однієї відповіді на питання»

На рисунку 4 показано два питання з трьома варіантами відповіді, серед яких одна $\epsilon$ правильною.

Нижче на рисунку 5 надаються приклади завдань зазначеного вище тесту, що передбачають вибір слова для правильного відтворення речення.

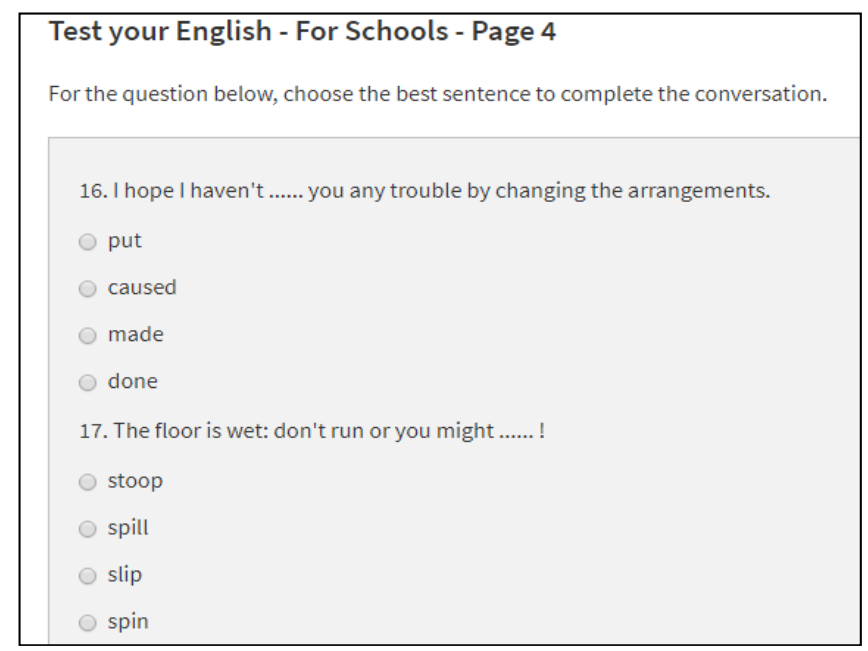

Рис. 5. Приклад тестового завдання типу «вибір слова для правильного відтворення речення» 
Після проходження тесту користувачу надаються рекомендації щодо вибору курсу для підвищення рівня володіння англійською мовою, при цьому не пропонується онлайн тест для отримання сертифікату про рівень володіння англійською мовою відповідно до Загальноєвропейських рекомендацій з мовної освіти.

Слід відзначити Кембриджскі екзамени (англ. Cambridge Examinations) «Англійська мова для носіїв інших мов» (англ. English For Speakers of Other Languages, ESOL), що належать до міжнародної системи тестування і надають можливість особистості пройти онлайн тест, отримати результати та рекомендації, пройти тест повторно та порівняти результат повторного тесту з попереднім. Тести Кембріджу визнано на міжнародному рівні та використовуються як критерії міжнародних досліджень або для працевлаштування в англомовних країнах й часто пропонуються як частина шкільної програми. Основна група іспитів містить п'ять тестів на визначення рівня володіння англійською мовою: Ключовий тест із англійської мови (Key English Test, KET), Попередній тест з англійської мови (Preliminary English Test, PET), Перший сертифікат 3 англійської мови (First Certificate in English, FCE), Сертифікат iз просунутого рівня володіння англійською мовою (Certificate in Advanced English, CAE), Сертифікат із майстерного рівня володіння англійською мовою (Certificate of Proficiency in English, CPE).

KET (https://www.examenglish.com/KET/index.html) - це перший із кембриджських іспитів на визначення рівня володіння англійською мовою. Він розрахований на кандидатів з базовим знанням англійської мови (рівень Pre-Intermediate), які вміють читати короткі рекламні оголошення, вивіски на вулиці, вказівки, інструкції, вміють підтримувати коротку бесіду. Екзамен КЕТ складається з трьох частин:

1) читання та письмо (Reading \& Writing), що складається 356 питань, на які надається 70 хвилин;

2) слухання (аудіювання), на яке надається 25 хвилин;

3) говоріння, на яке надається $8-10$ хвилин.

Тест має дві версії: для всіх бажаючих та спеціалізовану для шкіл.

Частина «Читання та письмо» охоплює вісім таких компонентів (рис. 6):

Читання:

1 - підписи та короткі тексти (англ. sign and short texts);

2 - відтворення речень (англ. gapped sentences);

3 - розмова с вибором декількох питань (англ. conversation with multiple choice questions);

4 - довгі тексти с вибором декількох питань (англ. long text with multiple choice questions);

5 - тексти з пропусками та вибором одного правильного варіанту з чотирьох (англ. text with multiple choice gaps);

Письмо:

6 - завершення слова (англ. word complection);

7 - текст із пропусками (англ. text with gaps);

8 - заповнення форми (англ. fill in a form). 


\begin{tabular}{|l}
$\begin{array}{l}\text { Advertisements } \\
\text { SPONSORED SEARCHES }\end{array}$ \\
EET Ream Practice Test \\
The Cambridge English: Key Reading and Writing paper has nine parts and different types of \\
texts and questions. Parts $1-5$ are about reading and Parts $6-9$ are mainly about writing. \\
Reading and Writing are taken together - 70 minutes \\
1. Reading part 1: signs and short texts \\
2. Reading part 2: gapped sentences \\
3. Reading part 3: conversations with multiple choice questions \\
4. Reading part 4: long text with multiple choice questions \\
5. Reading part 5: text with multiple choice gaps \\
6. Writing part 1: word completion \\
7. Writing part 2: text with gaps \\
8. Writing part 3: fill in a form
\end{tabular}

Рис. 6. Фрагмент сторінки, де пропонується користувачу пройти онлайн тест за частиною "Читання та письмо»

Онлайн-форма цих тестів надає можливість відразу отримати результати відповідей та у випадку, якщо результат негативний, пройти цей тест ще раз, що дозволить користувачеві повторити матеріал, самостійно оцінити свої знання та безперервно навчатися, підвищуючи свій рівень володіння англійською мовою (рис. 7).

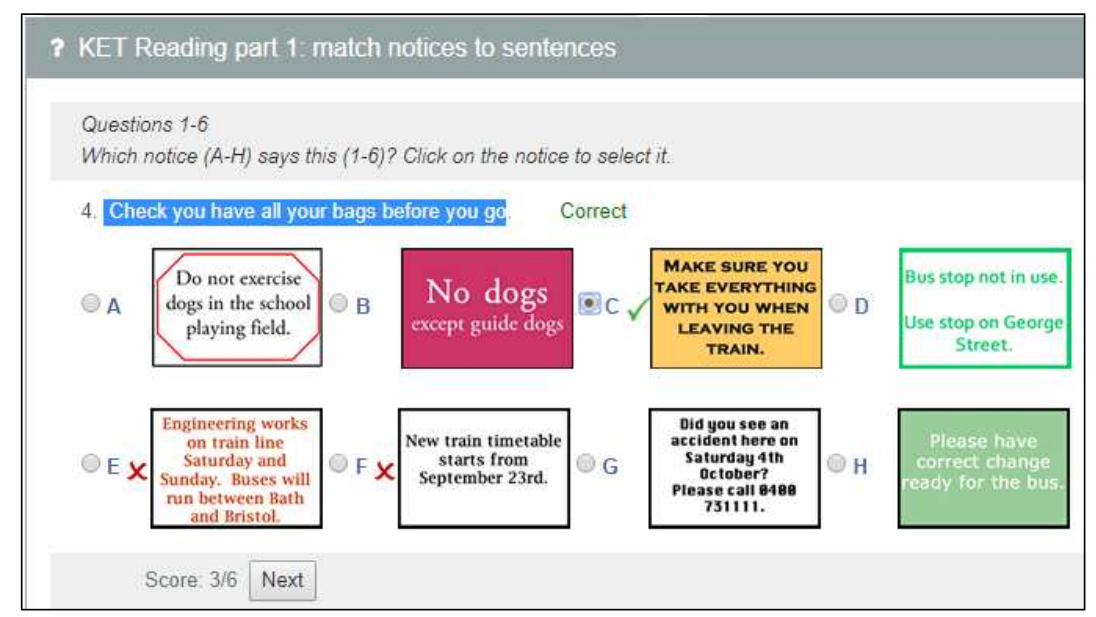

Рис. 7. Приклад відповіді на питання першої частини тесту «Читання та письмо» - підписи та короткі тексти

На рисунку 7 надано приклад відповіді на питання першої частини тесту «Читання та письмо» першого компоненту «підписи та короткі тексти», де вказано, що дві відповіді були неправильними, отже користувач мав замислитись та знайти правильну відповідь, що мало посприяти мотивації ще раз уважно прочитати питання та відповіді на нього. Тест користувач може проходити стільки разів, скільки він бажає.

PET (https://www.examenglish.com/PET/index.html) - це тест, розроблений для студентів, які володіють англійською мовою на рівні Intermediate або В1 відповідно до Загальноєвропейської системи оцінки знання іноземних мов. Екзаменаційні завдання припускають наявність у кандидатів навичок усного та писемного мовлення, достатніх для повсякденного спілкування. Він, як і попередній тест, складається з трьох частин:

1) читання та письмо, на які надається 90 хвилин;

2) слухання (аудіювання), на яке надається 30 хвилин;

3) говоріння, на яке надається 10 хвилин.

FCE (https://www.examenglish.com/FCE/index.php) є тестом, за допомогою якого відбувається оцінювання володіння особистістю англійською мовою на рівні В2. Він 
може проходити в онлайн режимі або на папері й складається з чотирьох частин, а саме:

1) читання та використання англійської мови (англ. Reading \& Use of English), на які надається 75 хвилин;

2) письмо, коли потрібно написати два есе протягом 80 хвилин;

3) слухання (аудіювання), на яке надається 40 хвилин;

4) говоріння, що являє собою інтерв'ю, як правило, з іншим кандидатом, на яке надається 14 хвилин.

Після успішного проходження тесту FCE кандидат отримує сертифікат рівня В2.

Так, наприклад, частина «Читання та використання англійської мови» в онлайн режимі складається з семи компонентів, кожний з яких містить два тестових завдання: choice cloze);

1 - вибір правильної відповіді з багатьох варіантів відповідей (англ. multiple

2 - відкриті тестові завдання, текст із пробілами (англ. open cloze, text with gaps);

3 - словотворення (англ. word formation);

4 - трансформації ключових слів (англ. key word transformations);

5 - текст і шість питань до нього з вибором варіантів відповідей (англ. text with 6 multiple choice questions);

6 - текст $з$ пропущеними реченнями та шість варіантів відповідей (англ. text with 6 sentences missing);

7 - різні тексти та 10 питань до них із вибором одного правильного варіанту відповіді з чотирьох запропонованих (англ. multiple matching, 10 questions).

Кожна правильна відповідь у компонентах 1 - 3 надає користувачу 1 бал; кожна правильна відповідь у компоненті 4 - 2 бали. Для компонентів 5 - 6 кожна правильна відповідь надає користувачу 2 бали; для компонента 7 кожна правильна відповідь - 1 бал.

Варто відзначити, що до тестових завдань пропонуються чіткі інструкції щодо їх виконання, онлайн тести мають зручні форми та швидкий зворотний зв'язок.

Нижче на рисунку 8 надається приклад онлайн тестового завдання 3 вибором правильної відповіді з багатьох варіантів.

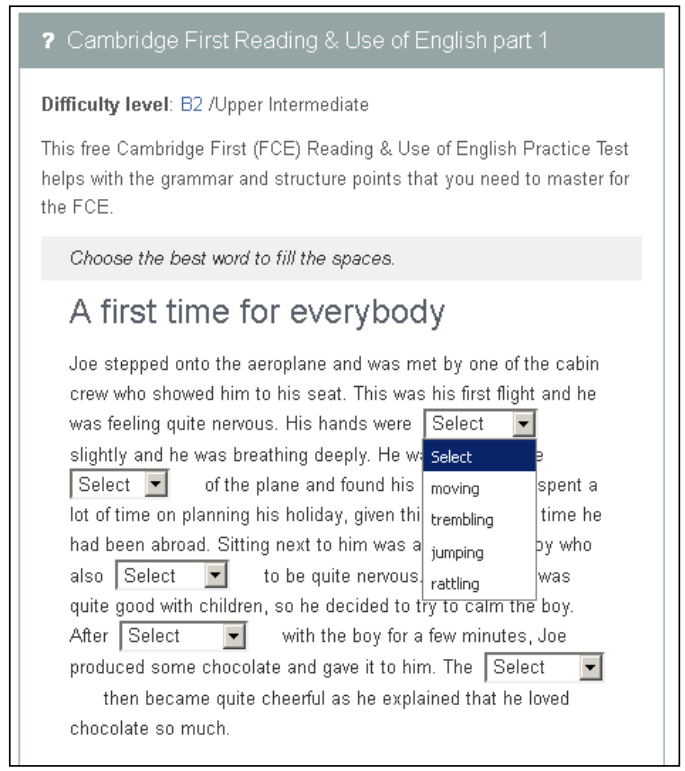

Рис. 8. Приклад уривка тестового завдання з вибором правильної відповіді з багатьох варіантів відповідей 
На рисунку 8 вказано, що в комірці вибору (англ. Select) слід обрати найбільш доречне слово, що буде відповідати логіці речення в тексті. Після закінчення користувачем тестового завдання вказуються помилки та бали, які він заробив за виконане завдання.

На наступному рисунку 9 показано зроблене завдання.

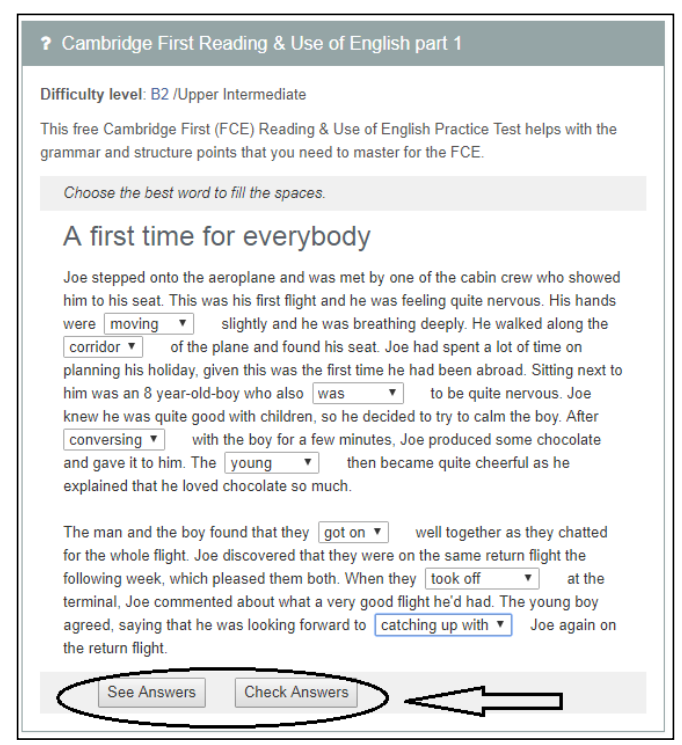

Рис. 9. Зроблене завдання з вибором правильної відповіді з багатьох варіантів відповідей

На рисунку 9 - зроблене завдання 3 вибором правильної відповіді з багатьох варіантів відповідей, що було представлено на рисунку 8. Слід зауважити, що 3 навчальною метою користувачу варто вибрати (вказано стрілкою) «check answers», що надасть можливість побачити свої помилки та проаналізувати їх (рис. 10).

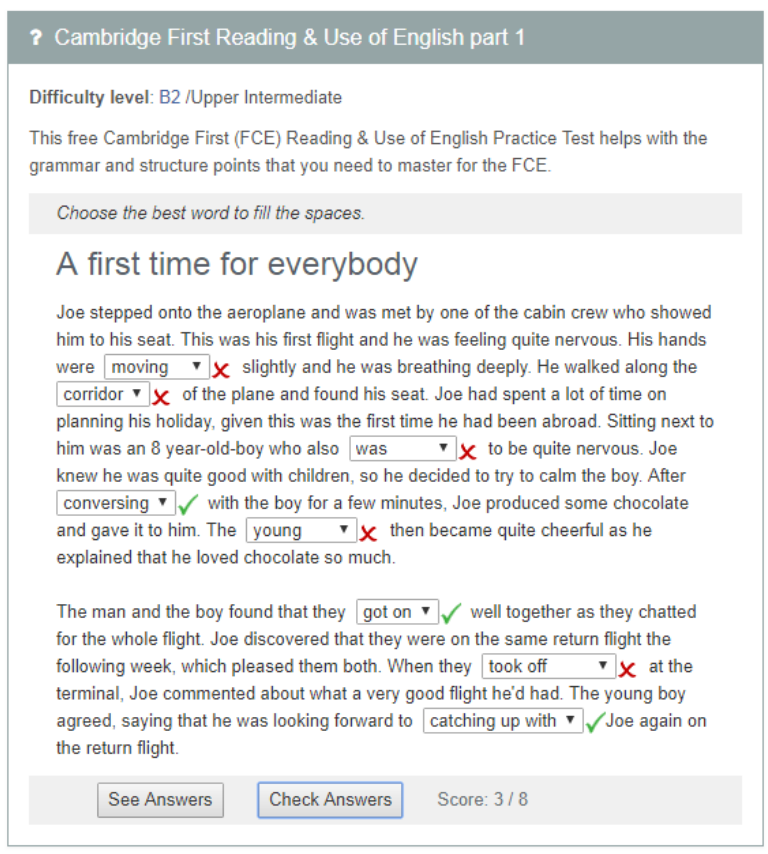

Рис. 10. Результат проходження тестового завдання з вибором правильноӥ відповіді з багатьох варіантів відповідей, уривок якого надається на рисунку 8 
Отже, на рисунку 10 відображено результат пройденого тестового завдання, уривок якого надається на рисунку 8: галочками вказано правильні, а хрестиками неправильні відповіді. Так, для більш вдалого результату, користувач має слідувати настановам та рекомендаціям, що надаються перед тестом, а саме:

- слід пам’ятати, що тест перевіряє вміння і навички читання, знання лексики та граматики;

- слід якомога більше читати та використовувати словник, щоб вивчити нові слова;

- слід використовувати підручники 3 граматики, що допоможе зрозуміти структуру речення;

- перед початком проходження кожного тестового завдання слід уважно прочитати інструкції;

- перш ніж відповідати на будь-які питання, слід прочитати текст до кінця;

- слід пам'ятати, що тексти, які використовуються в Кембриджському екзамені, можуть бути різними за стилем та жанром, а саме - газетними та журнальними статтями, доповідями, фантастичними оповіданнями, рекламними оголошеннями, інформаційними матеріалами (брошури, довідники та ін.).

CAE - Кембриджський іспит, який підтверджує високий рівень володіння мовою (Advanced 2 або С1 відповідно до Загальноєвропейських Рекомендацій з мовної освіти) кандидата, здатного використовувати англійську в навчальних і робочих цілях, вільно спілкуватись цією мовою і вести ділові переговори. Наявність сертифіката САE $\epsilon$ достатньою умовою для вступу до більшості британських вузів і пошуку роботи в європейських компаніях.

Цей тест, як і описаний вище, складається з чотирьох частин:

1) читання та використання англійської мови (англ. Reading \& Use of English), що містить 56 питань,на які надається 90 хвилин;

2) письмо, коли потрібно написати два есе протягом 90 хвилин;

3) слухання (аудіювання), на яке надається 40 хвилин для відповіді на 30 питань;

4) говоріння, що являє собою інтерв'ю, як правило, з іншим кандидатом, на яке надається 15 хвилин.

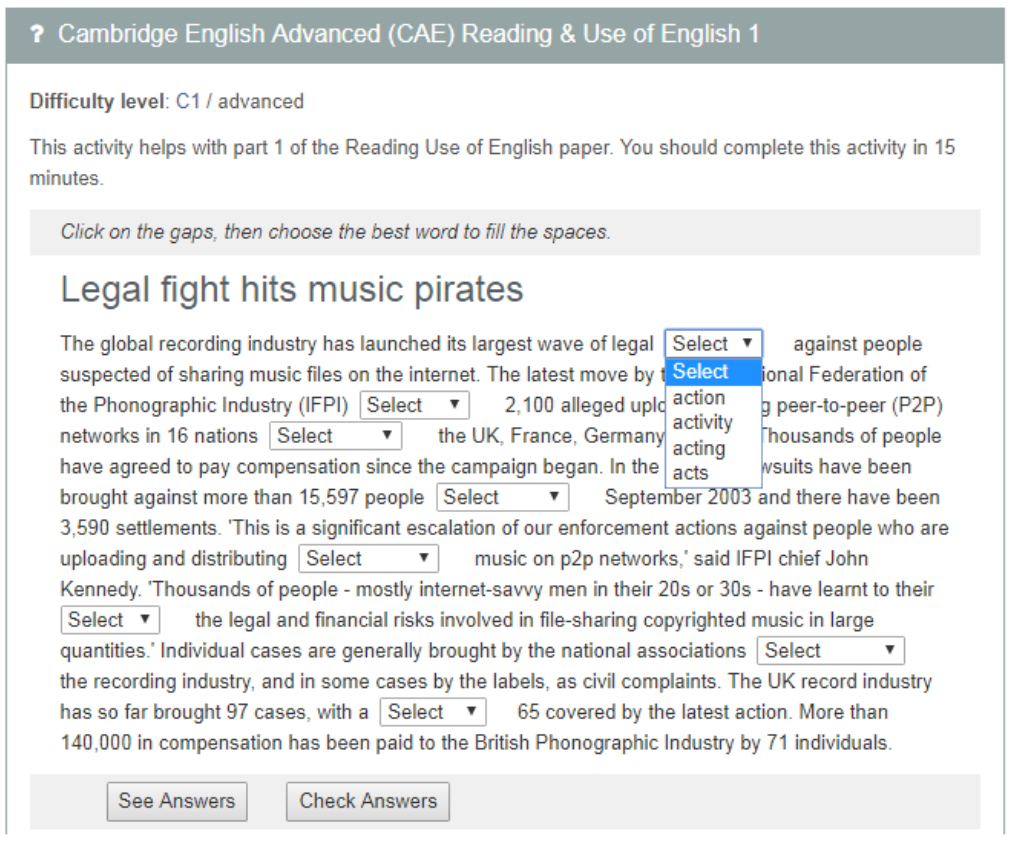

Рис.11. Приклад тестового завдання 
На рисунку 11 наведено приклад тестового завдання першої частини тесту СAE «Читання та використання англійської мови». Слід звернути увагу, що незважаючи на коротший текст у тесті CAE, ніж у тесті FCE, він $є$ складнішим через використання в ньому специфічної термінології, наприклад, «Міжнародна федерація фонографічної промисловості» (англ. International Federation of the Phonographic Industry, IFPI), «рівний-рівному» (англ. peer-to-peer, Р2P) та ін.

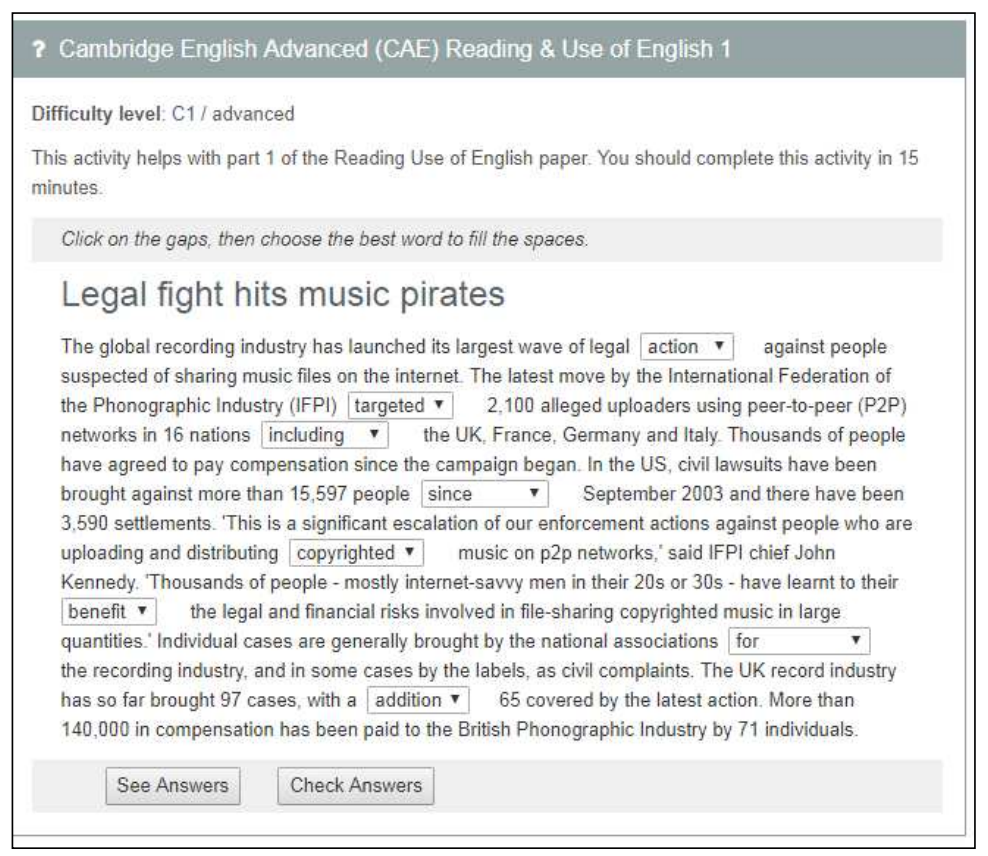

\section{Рис. 12. Приклад зробленого завдання тесту САЕ «Читання та використання} англійської мови»

Нижче на рисунку 13 надається результат проходження тестового завдання тесту САЕ «Читання та використання англійської мови», що зображений на рисунку 12.

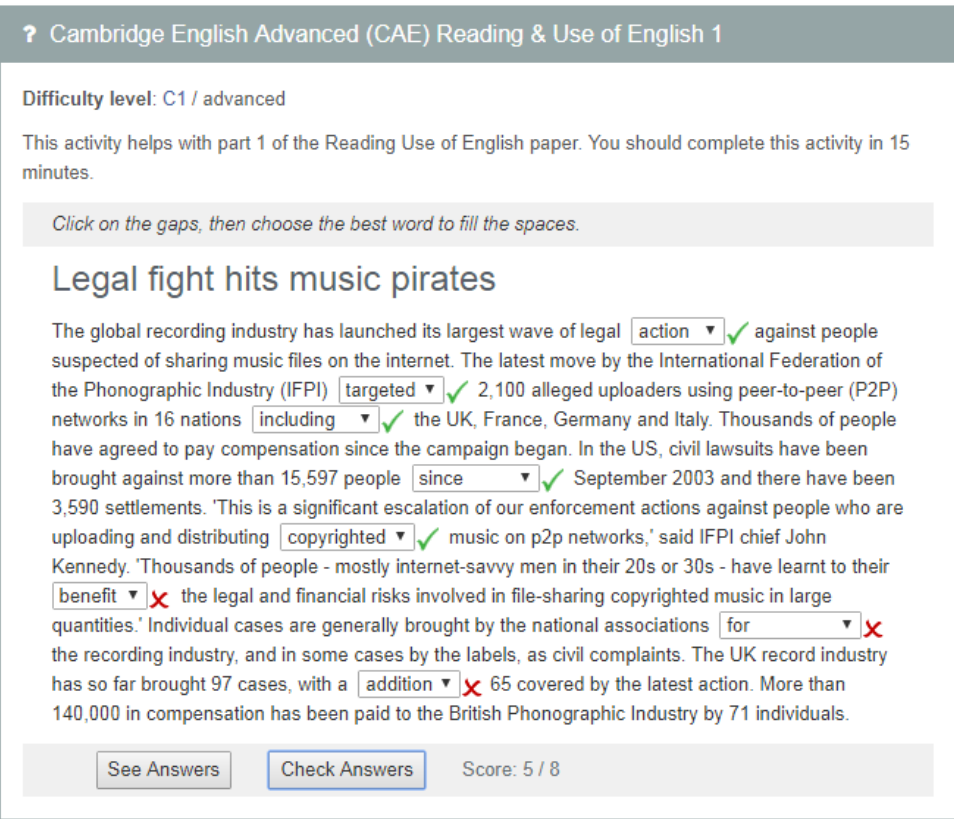

Рис. 13. Результат проходження тестового завдання тесту САЕ «Читання та використання англійської мови», що зображений на рисунку 12 
Результат проходження тестового завдання тесту САЕ «Читання та використання англійської мови» на рисунку 13 свідчить про те, що користувач має проаналізувати помилки та пройти це завдання ще раз, оскільки правильних відповідей повинно бути стільки, скільки питань, тобто вісім питань - вісім правильних відповідей.

CPE (https://www.examenglish.com/cpe/index.php) - це [8] сертифікат, який підтверджує ступінь володіння мовою на рівні носія мови (англ. Proficiency). Кандидати на складання цього іспиту повинні досконало володіти англійською мовою, мати великий досвід англомовного спілкування в різних сферах діяльності, зокрема діловій та академічній.

Тест має п'ять розділів:

- читання - 4 частини, на виконання яких надається 90 хвилин (частина 1 - 3 тексти з 18 пропусками; частина 2 - 4 пов'язані тексти 3 двома питаннями до кожного; частина 3 - текст 3 відсутніми параграфами; частина 4 - текст із запитами з множинним вибором відповідей;

- композиція - 2 завдання, на виконання яких надається 2 години;

- використання англійської мови - 3 частини, на виконання яких надається 90 хвилин (частина 1 - текст із 15 пропусками; частина 2 - формування слів; частина 3 - відновити пропущені речення);

- слухання - 3 або 4 записи, на виконання яких надається 40 хвилин;

- інтерв'ю - зазвичай з іншим кандидатом, на виконання якого надається 15 хвилин.

Тест СРЕ має онлайн форму тільки для чотирьох розділів, частина «композиція»тільки в паперовій формі.

Крім зазначених вище онлайн тестів Кембриджського екзамену, також на особливу увагу заслуговує, на нашу думку, Інтернет орієнтований тест з англійської мови як іноземної (англ. Internet-based Test Of English as a Foreign Language, TOEFL iBT) [12], який має суттєву історію розвитку, що свідчить про його високу валідність завдяки постійному моніторингу та корегуванню.

\begin{tabular}{|c|c|}
\hline (i) https://www.ets.org/toefl & \\
\hline \multicolumn{2}{|l|}{ The TOEFL ${ }^{\circledR}$ Test } \\
\hline $\begin{array}{l}\text { The TOEFL }{ }^{\circledast} \text { Test Gives You an Advantage: } \\
\text { Most Widely Accepted, Most Popular and } \\
\text { Most Convenient Choice }\end{array}$ & $\begin{array}{c}\text { TOEFL iBT }{ }^{\circledR} \text { Test }> \\
\text { - About the Test }\end{array}$ \\
\hline The TOEFL test is the most widely respected & Register for the Test \\
\hline English-language test in the world, recognized by & - Test Centers and Dates \\
\hline more than 10,000 colleges, universities and & - Prepare for the lest \\
\hline agencies in more than 130 countries, including & - On Test Day \\
\hline Australia, Canada, the U.K. and the United & - Scores \\
\hline States. Wherever you want to study, the TOEFL & - Frequently Asked Questions \\
\hline test can help you get there. & $\begin{array}{l}\text { - Test Takers with Disabilities and Health-related } \\
\text { Needs }\end{array}$ \\
\hline Register Now & \\
\hline Who Accepts TOEFL Scores ? & TOEFL ${ }^{\circledR}$ Paper-delivered Testing \\
\hline Upcoming Student Fairs > & This year we are launching the revised TOEFL ${ }^{\otimes}$ \\
\hline Sign Up For Emails > & Paper-delivered Test, a new paper-and-pencil test \\
\hline TOEFL Family of Assessments > & $\begin{array}{l}\text { that is more closely aligned to the } \operatorname{TOEFL} i B T^{\mathbb{E}} \text { test. } \\
\text { The first test administration was October } 14,2017 \text {. }\end{array}$ \\
\hline & $\begin{array}{l}\text { The TOEFL }{ }^{\oplus} \text { PBT test is no longer administered, but } \\
\text { your scores are valid for } 2 \text { years after your test date. } \\
\text { For more information, including how to order } \\
\text { additional score reports, see } T_{O E F L}{ }^{\circledR} \text { PBT test. }\end{array}$ \\
\hline
\end{tabular}

Pис. 14. Фрагмент офіційного сайту TOEFL iBT, де стрілкою позначено посилання для реєстрачї̈ користувача

Так, TOEFL був створений у 1961 році експертами авторитетних організацій у галузі вищої освіти з багаторічним досвідом проведення тестів, як Center for Applied Linguistics, 
Modern Language Association, The College Board, ETS i GRE. 31973 року управління програмою тестування під керівництвом Ради TOEFL здійснюється організацією Освітня служба тестування (англ. Educational Testing Service, ETS), якій належать авторські права на іспит. У процесі своєї еволюції формат і зміст тесту багато разів змінювались. На даний час найпоширенішим форматом іспиту є запроваджене в 2005 році Інтернет тестування (https://www.ets.org/toefl). Для проходження цього тесту користувачу необхідно зареєструватися на офіційному сайті TOEFL iBT - ets.org/toefl (рис. 14).

Після реєстрації кандидату пропонується ознайомитись 3 тестовими матеріалами, що викладені на сайті у форматі PDF та DOC.

TOEFL, як і попередньо описані тести, охоплює оцінювання знань, умінь i навичок володіння мовою за чотирма основними критеріями, а саме: читання, слухання (аудіювання), говоріння та писання (таблиця 1).

Табличя 1.

\section{Структура TOEFL}

\begin{tabular}{|c|c|c|c|}
\hline $\begin{array}{l}\text { Розділи } \\
\text { TOEFL }\end{array}$ & $\begin{array}{l}\text { Час, що надається } \\
\text { для виконання } \\
\text { завдань }\end{array}$ & $\begin{array}{c}\text { Кількість } \\
\text { питань }\end{array}$ & Опис завдання \\
\hline Читання & 60-80 хвилин & $\begin{array}{l}\text { 36-56 } \\
\text { питань }\end{array}$ & $\begin{array}{l}\text { Прочитайте } 3 \text { або } 4 \text { уривки } 3 \\
\text { академічних текстів та дайте відповіді на } \\
\text { запитання }\end{array}$ \\
\hline Слухання & 60-90 хвилин & $\begin{array}{l}\text { 34-51 } \\
\text { питання }\end{array}$ & $\begin{array}{l}\text { Прослухайте лекції, дискусії та бесіди, } \\
\text { потім відповідайте на питання }\end{array}$ \\
\hline Перерва & 10 хвилин & - & - \\
\hline Говоріння & 20 хвилин & 6 завдань & $\begin{array}{l}\text { Висловлюйте думку зі знайомої теми; } \\
\text { прочитайте та прослухайте завдання, } \\
\text { потім відповідайте на питання }\end{array}$ \\
\hline Писання & 50 хвилин & 2 завдання & $\begin{array}{l}\text { Напишіть есе на основі завдань } 3 \\
\text { читання та прослуховування; викладіть } \\
\text { думку в письмовій формі. }\end{array}$ \\
\hline
\end{tabular}

У таблиці 1 подається структура TOEFL для тих, хто вже готовий складати екзамен. Онлайн-тренажер TOEFL для пробного екзамену знаходиться за електронною адресою https://www.examenglish.com/TOEFL/TOEFL_iBt.html, де можна пройти такі розділи тесту в онлайн-форматі як читання, слухання та говоріння.

Слід відзначити, що ще одним із популярних міжнародних іспитів на знання англійської мови є тест Міжнародної тестової системи 3 англійської мови (англ. International English Language Testing System, IELTS) [13].

Iсторія IELTS починається з 1976 року за ініціативи Служби тестування англійської мови та Британської ради. Він був створений для оцінювання англійської мови аспірантів [14]. 
В Австралії в 1988 році цей тест починає використовуватись для перевірки знань англійської мови абітурієнтів та студентів.

У 1989 році була затверджена структура IELTS, що містила два модулі Академічний та Загальний, які мають, як і попередньо розглянуті тести, чотири розділи: слухання, читання, письмо, говоріння [14]. У розділі читання та написання академічного модуля було виокремлено три категорії А, В та С для перевірки мовних навичок у конкретних галузях, а саме: науки, науки та технології, науки про життя, соціальних наук.

Tест IELTS набуває популярності у близько 200 тест-центрів по всьому світу, що постійно стежать за заходами Міжнародної програми розвитку (англ. International Development Program, IDP) Австралії, Британської Ради та Синдикату місцевої експертизи Кембриджського університету (англ. University of Cambridge Local Examination Syndicate) [13].

У 1995 році почала розроблятись веб-система IELTS для перевірки результатів тестування [14].

Так, онлайн-формат IELTS для пробного проходження тесту без реєстрації розміщено за адресою https://takeielts.britishcouncil.org/prepare-test/free-practice-tests (рис. 15).

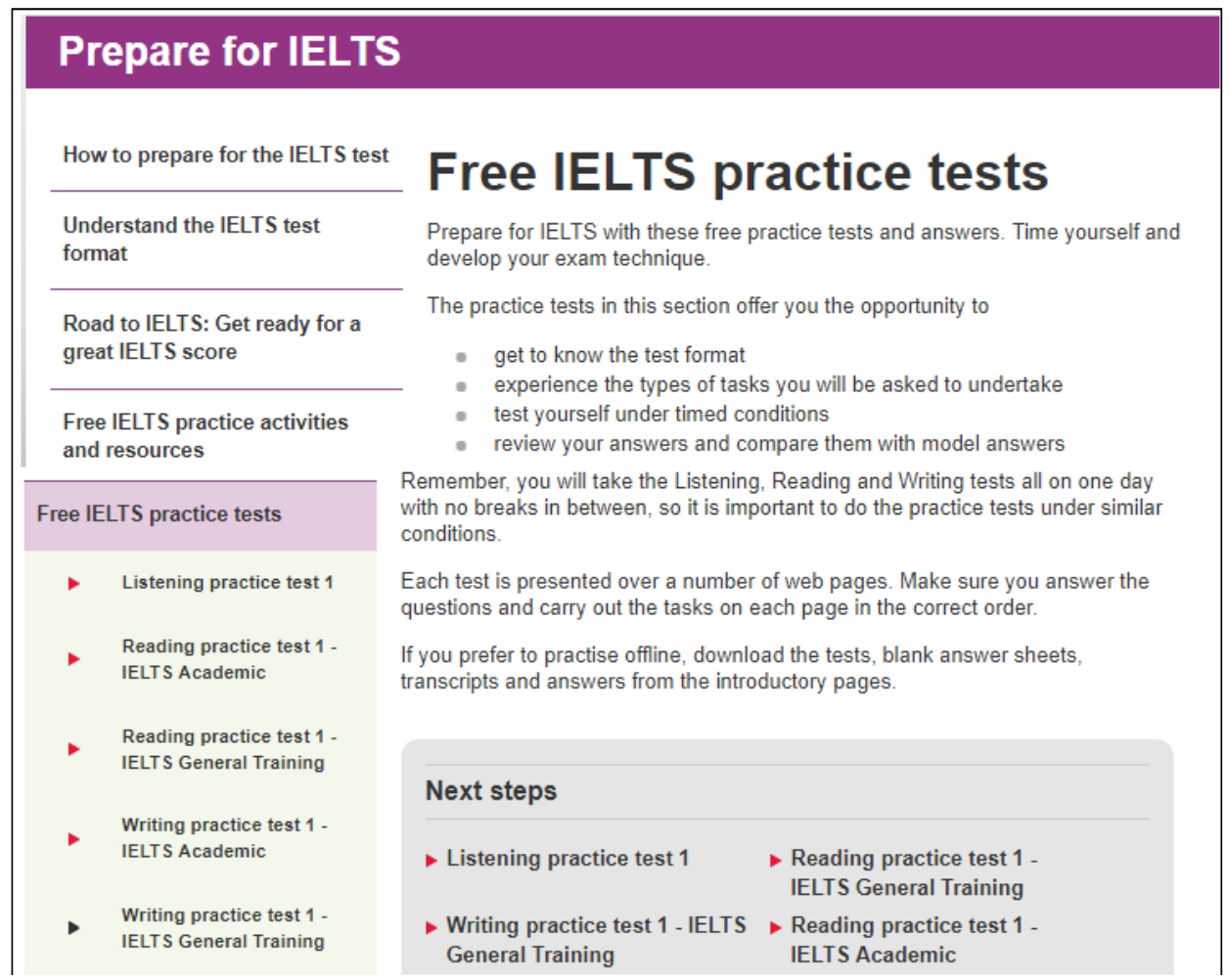

Рис. 15. Фрагмент сайту онлайн-формату IELTS для пробного проходження тесту без реєстраиіiі

В онлайн-форматі тесту є можливість встановити час випробування та розробити свою індивідуальну техніку його проходження; ознайомитись із форматом тесту та типами завдань; переглянути свої відповіді та порівняти їх з правильними.

На рисунку 16 надається приклад тестового завдання IELTS. 
Step 1 - Take our free English level test

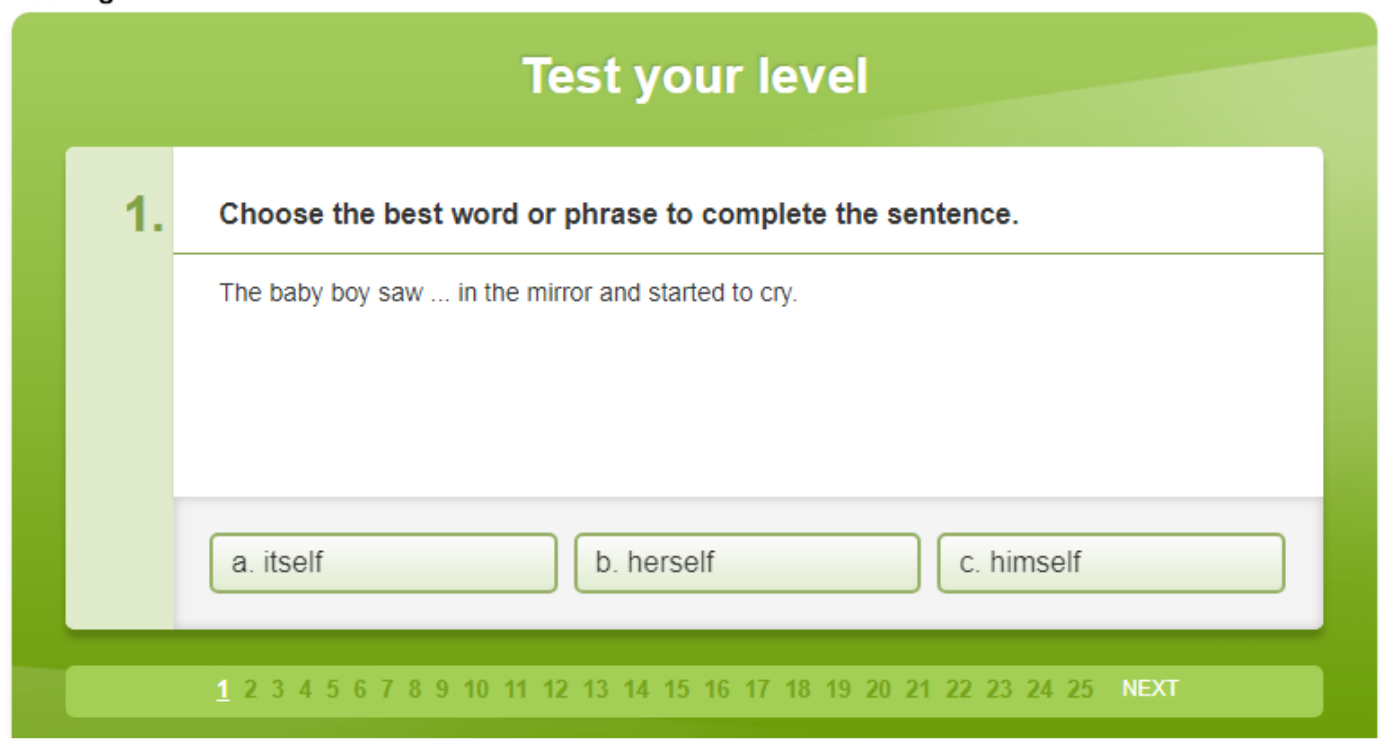

Рис. 16. Приклад тестового завдання IELTS

Слід зазначити, що після вибору варіанту відповіді, кандидату пропонується відповісти на питання чи «впевнений», «не зовсім впевнений», «не впевнений» у своєму рішенні.

Коли кандидат пройде всі тестові завдання, він отримую результат оцінювання свого рівня володіння англійською мовою, як, наприклад, на рисунку 17.

\section{Step 1 - Take our free English level test}

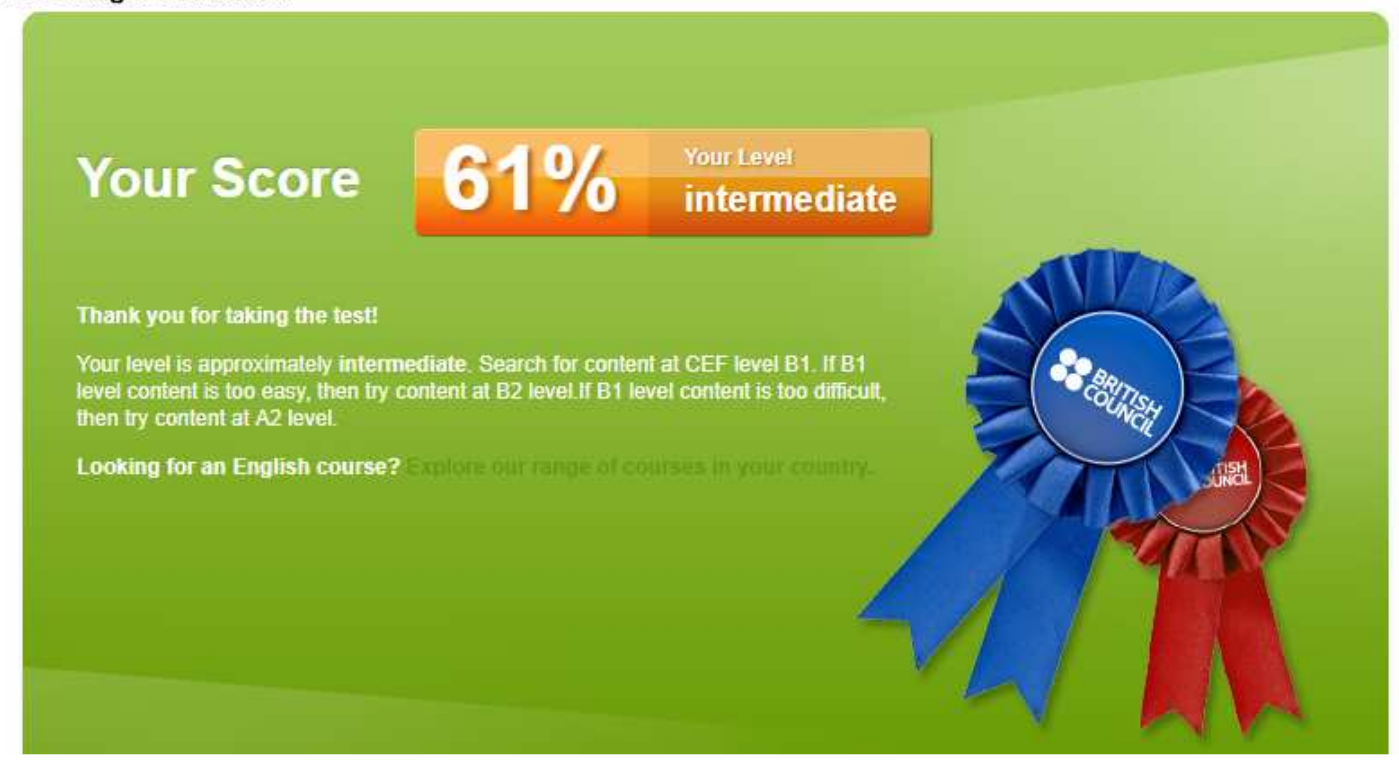

Рис. 17. Приклад результату оичінювання IELTS

Так, на рисунку 17 представлений результат оцінювання IELTS, який свідчить, що рівень володіння англійською мовою того, хто проходив тест, між А2 та В1 і йому запропоновано пройти курс для підвищення рівня.

До цього тесту також пропонується безкоштовна підготовка на офіційному сайті British Council (http://learnenglish.britishcouncil.org/en), що містить теоретичний матеріал та онлайн тести відповідно до наданої теорії. Крім цього надається можливість пройти 
онлайн тест та з'ясувати особистий рівень володіння англійською мовою (http://learnenglish.britishcouncil.org/en/content) відповідно до Загальноєвропейських рекомендацій з мовної освіти: вивчення, викладання, оцінювання.

3 огляду на описані вище тести, у таблиці 2, узагальнено основні їх характеристики.

Таблиия 2.

Основні характеристики розглянутих онлайн тестів

\begin{tabular}{|c|c|c|c|c|c|}
\hline $\begin{array}{c}\text { Онлайн } \\
\text { тест }\end{array}$ & $\begin{array}{l}\text { Миттєвий } \\
\text { зворотний } \\
\text { зв'язок без } \\
\text { реєстрації на } \\
\text { сайті }\end{array}$ & $\begin{array}{l}\text { Зворотний } \\
\text { зв'язок } \\
\text { через } \\
\text { електронну } \\
\text { пошту } \\
\text { після } \\
\text { реєстрації }\end{array}$ & $\begin{array}{l}\text { Можливість } \\
\text { багаторазового } \\
\text { проходження } \\
\text { тесту }\end{array}$ & $\begin{array}{l}\text { Можливість } \\
\text { порівнювати та } \\
\text { відслідковувати } \\
\text { свої результати } \\
\text { проходження } \\
\text { тесту після } \\
\text { реєстрації }\end{array}$ & $\begin{array}{l}\text { Онлайн- } \\
\text { тренажер } \\
\text { для всіх } \\
\text { завдань }\end{array}$ \\
\hline Key & + & + & + & - & + \\
\hline KET & + & + & + & - & + \\
\hline PET & + & + & + & - & + \\
\hline FCE & + & + & + & - & + \\
\hline $\mathrm{CAE}$ & + & + & + & - & - \\
\hline $\mathrm{CPE}$ & + & + & + & - & - \\
\hline $\begin{array}{l}\text { TOEFL } \\
\text { iBT }\end{array}$ & - & + & + & + & - \\
\hline IELTS & + & + & + & - & + \\
\hline
\end{tabular}

У таблиці 2 визначені основні характеристики онлайн тестів Кеу, KET, PET, FCE, CAE, CPE, TOEFL iBT та IELTS, які можуть зацікавити користувачів, а саме: всі онлайн тести, крім TOEFL iBT, забезпечують миттєвий зворотний зв'язок без реєстрації на сайті; всі тести мають зворотний зв'язок через електронну пошту після реєстрації та можливість багаторазового проходження тесту; можливість порівнювати та відслідковувати свої результати проходження тесту після реєстрації пропонується тільки в TOEFL iBT, оскільки створюється особистий профіль користувача, де зберігаються всі його варіанти відповідей; онлайн тренажер для всіх модулів (розділів) пропонується у тестах Kеy, KET, PET, FCE та IELTS.

Так, згідно 3 таблицею 2, можна зазначити, що описані онлайн тести $\epsilon$ інструментами для контролю, самоконтролю, підтримки навчання та самонавчання, а також мотивації для навчання англійській мові як студентів 3ВО, так і будь-кого, хто бажає підвищити свій рівень володіння англійською мовою.

\section{3. ВИСНОВКИ ТА ПЕРСПЕКТИВИ ПОДАЛЬШИХ ДОСЛІДЖЕНЬ}

Отже, було виокремлено, проаналізовано та схарактеризовано основні міжнародні онлайн тести, що можуть забезпечувати самонавчання та самооцінювання, для об' єктивного оцінювання рівня володіння англійською мовою студентів 3ВО, а саме: Кембриджської шкали оцінки професійних компетентностей викладачів іноземної мови; Кембриджского екзамену - Ключовий тест з англійської мови (KET), Попередній тест з англійської мови (РET), Перший сертифікат з англійської мови (FCE), Сертифікат iз прогресивним рівнем володіння англійською мовою (САE), Сертифікат із 
майстерним рівнем володіння англійською мовою (СРЕ); Інтернет орієнтованого тесту 3 англійської мови як іноземної (TOEFL iBT) та Міжнародної тестової системи англійської мови (IELTS). Ці тести загалом складаються з чотирьох частин (читання, слухання, говоріння, письмо) та базуються на Загальноєвропейських рекомендаціях 3 мовної освіти: вивчення, викладання, оцінювання. Ці тести є зручним інструментом у процесах викладання англійської мови та навчання мові, оскільки забезпечують: викладачу - зручну швидку перевірку рівня володіння студентом англійською мовою, можливість переглянути типові помилки та обговорити їх із студентами для корегування їхнього подальшого плану навчання, підвищити рівень викладання іноземної мови завдяки використанню онлайн тестів; студенту - можливості неперервного навчання англійській мові та постійного підвищення свого рівня володіння мовою для отримання в подальшому необхідного сертифіката.

Було з'ясовано, що онлайн тести, що мають довгу історію розвитку, мають суттєву валідність та високу репутацію серед викладачів англійської мови і кандидатів на проходження іспитів з англійської мови як іноземної.

Перспективами подальших досліджень є впровадження міжнародних онлайн тестів в освітній процес ЗВО для проведення оцінювання рівня володіння англійською мовою та аналіз впливу цих інструментів на рівень іншомовної компетентності студентів.

\section{СПИСОК ВИКОРИСТАНИХ ДЖЕРЕЛ}

[1] Т. О. Вольфовська, "Комунікативна компетентність молоді як одна 3 передумов досягнення життєвої мети”, Шлях освіти. 2001. N 3. С. 13-16.

[2] Descriptors of Key Competences in the National Qualification Framework. Competences of Personal Development. [Електронний ресурс]. Доступно: http://cpd.yolasite.com/key-competences.php. Дата звернення: травень 23, 2018.

[3] Л.В. Сазанович, “Досвід використання автентичних підручників з мови спеціальності у медичному вузі”. Наукові записки Національного університету "Острозька академія". Серія : Філологічна, Вип. 42. С. 298-300, 2014. [Електронний ресурс]. Доступно: http://nbuv.gov.ua/UJRN/Nznuoaf_2014_42_91. Дата звернення: травень 23, 2018.

[4] Generic Competences [Еектроннй ресу. Доступн: http://www.unideusto.org/tuningeu/competences/generic.html. Дата звернення: травень 12, 2018.

[5] D. Lasagabaster, 2008. Foreign language competence in content and language integrated courses. The Open Applied Linguistics Journal, I: 31-42.

[6] С. Ю. Ніколаєва, “Основи сучасної методики викладання іноземних мов”, К.: Ленвіт. 285 с. , 2008.

[7] Н. С. Нікітіна, "Використання мультимедійних засобів у викладанні іноземної мови професійного спрямування у вищій школі” [Електронний ресурс]. Доступно: http://confesp.fl.kpi.ua/ru/node/1096. Дата звернення: травень 23, 2018.

[8] C. M. Clarke, \& M. F. Garrett, "Rapid adaptation to foreign-accented English". The Journal of the Acoustical Society of America, 116 (6), 3647-3658, 2004.

[9] A. M. Pinto-Llorente, M. C. Sánchez-Gómez, F. J. García-Peñalvo, \& S. Casillas Martín, "The use of online quizzes for continuous assessment and self-assessment of second-language learners”. In F. J. García-Peñalvo (Ed.), Proceedings of the Fourth International Conference on Technological Ecosystems for Enhancing Multiculturality (TEEM'16) (Salamanca, Spain, November 2-4, 2016) (pp. 819-824). New York, NY, USA: ACM. doi:10.1145/3012430.3012612

[10] A Common European Framework of Reference for Languages: Learning, Teaching, Assessment [Електронний ресурс]. Cambridge University Press. The Edinburgh Building Shaftesbury Road UKCB2 2RU Cambridge ROYAUME UNI. 200 p, 2001. Режим доступу: http://www.cambridge.org/uk. Дата звернення: травень 30, 2018.

[11] Cambridge English Language Assessment [Електронний ресурс]. Доступно: http://www.cambridgeenglish.org/images/172992-full-level-descriptors-cambridge-english-teachingframework.pdf. Дата звернення: травень 30, 2018.

[12] Mayette, Annaliese, "A thematic analysis of experiences of non-native English speaking international graduate students with the internet-based test of English as a foreign language." Dissertation Submitted in 
Partial Fulfillment of the Requirements for the Degree of Doctor pf Philosophy Educational Linguistics The University of New Mexico Albuquerque, New Mexico, 2014. [Електронний ресурс]. Доступно: http://digitalrepository.unm.edu/ling_etds/23. Дата звернення: травень 30, 2018.

[13] Cathy Lee T. Arcuino, "The relationship between the Test of English as a Foreign Language (TOEFL), the international English Language Testing System (IELTS) scores and academic success of international master's students". In partial fulfillment of the requirements For the Degree of Doctor of Philosophy Colorado State University Fort Collins, Colorado, 2013. [Електронний ресурс]. Доступно: https://dspace.library.colostate.edu/bitstream/handle/10217/78818/Arcuino_colostate_0053A_11657.pdf? sequence=1. Дата звернення: травень 12, 2018.

[14] Roger Hawkey, "Impact Theory and Practice Studies of the IELTS test and Progetto Lingue 2000", 2006 [Електронний ресурс]. Доступно: http://www.cambridgeenglish.org/images/329230-studies-inlanguage-testing-volume-24.pdf. Дата звернення: травень 26, 2018.

Матеріал надійшов до редакиї 27.07.2018 p.

\title{
ОНЛАЙН ИНСТРУМЕНТЫ ДЛЯ ОЦЕНИВАНИЯ ИНОЯЗЫЧНОЙ КОМПЕТЕНТНОСТИ СТУДЕНТОВ ВЫСШИХ УЧЕБНЫХ ЗАВЕДЕНИЙ: МЕЖДУНАРОДНЫЙ ОПЫТ
}

\author{
Чаюк Татьяна Андреевна \\ кандидат филологических наук, преподаватель кафедры иностранных языков юридического факультета \\ Киевский национальный университет имени Тараса Шевченко, г. Киев, Украина \\ ORCID ID 0000-0001-5318-688X \\ chajuk.t@gmail.com
}

\begin{abstract}
Аннотация. В статье освещены проблемы формирования и оценивания иноязычной компетентности студентов высших учебных заведений; дается анализ и характеристика основных международных онлайн тестов для объективного оценивания уровня владения английским языком студентами высших учебных заведений, что позволяет обеспечивать их самообучение и самооценивание. Описана структура международных онлайн тестов по английскому языку как иностранному и приведены примеры тестовых заданий. Выделены, проанализированы и охарактеризованы основные международные онлайн тесты, которые могут обеспечивать самообучение и самооценку, для объективного оценивания уровня владения английским языком студентами высших учебных заведений, а именно: тесты Кембриджской шкалы оценки профессиональных компетенций преподавателей иностранного языка; тесты Кембриджского экзамена, который включает в себя такие тесты, как Ключевой тест по английскому языку; Предварительный тест по английскому языку; Первый сертификат по английскому языку; Сертификат с прогрессивным уровнем владения английским языком; Сертификат с искусным уровнем владения английским языком; Интернет ориентированный тест по английскому языку как иностранному и Международная тестовая система английского языка. Анализ этих тестов показал, что они, в общем, состоят из четырех частей, таких как чтение, слушание, говорение, письмо, и базируются на общеевропейских компетенциях владения иностранным языком: изучение, преподавание, оценка. Эти тесты являются удобным инструментом в процессах преподавания английского языка и обучения языку, поскольку обеспечивают следующие функции: преподавателю - удобную быструю проверку уровня владения студентом английским языком, возможность посмотреть типичные ошибки и обсудить их со студентами для корректировки их дальнейшего плана обучения, возможность повысить уровень преподавания иностранного языка благодаря использованию онлайн тестов; студенту - возможности непрерывного обучения английскому языку и постоянного повышения своего уровня владения языком для получения в дальнейшем необходимого сертификата. Перспективами дальнейших исследований есть внедрение международных онлайн тестов в учебный процесс высшего учебного заведения для проведения оценки уровня владения английским языком и анализ влияния этих инструментов на уровень иноязычной компетентности студентов.
\end{abstract}


Ключевые слова: онлайн оценивание; онлайн тест; иноязычная компетентность, высшее учебное заведение.

\title{
ONLINE TOOLS FOR ASSESSMENT OF FOREIGN LANGUAGE COMPETENCE OF STUDENTS IN HIGHER EDUCATIONAL ESTABLISHMENTS: FOREIGN EXPERIENCE
}

\author{
Tetiana A. Chaiuk \\ PhD of Philological Sciences, Assistant Professor of the Foreign Languages Department, Faculty of Law \\ Kyiv National Taras Shevchenko University, Kyiv, Ukraine \\ ORCID ID 0000-0001-5318-688X \\ chajuk.t@gmail.com
}

\begin{abstract}
The article covers the problems of formation and assessment of foreign language competence of students of higher educational establishments; analyzes and describes the main international online tests for the objective assessment of the English language proficiency of students in higher educational establishments that can provide them with the possibilities of selfstudy and self-assessment. The structure of international online tests in English as a Foreign Language is described and examples of test tasks are given. The main international online tests for the objective assessment of the English language proficiency of students of higher educational establishments that can provide self-education and self-evaluation are singled out, analyzed, and characterized, namely: Cambridge English Teaching Framework; Cambridge Examinations, which includes such tests as Key English Test (KET); Preliminary English Test (PET); First Certificate in English (FCE); Certificate of Proficiency in English (CPE); Certificate in Advanced English (CAE); Certificate of Proficiency in English (CPE); Internet-based Test Of English as a Foreign Language (TOEFL iBT) and International English Language Testing System (IELTS). As analysis of these tests showed, they generally consist of four parts, such as reading, listening, speaking, writing, and are based on the European-wide recommendations on language education, namely: studying, teaching, assessment. These tests are a convenient tool in English language teaching and learning, since they provide the following functions: for the teacher - a convenient quick check of the level of students' proficiency in English, an opportunity to spot typical mistakes and discuss them with students in order to direct their further studies, an opportunity to improve the level of teaching a foreign language by use of online tests; for students - the possibility of continuing education in English and continuous improvement of their level of language proficiency with a view to obtaining the necessary certificate in further perspective. A promising direction of further studies seems to be the introduction of international online tests in the educational process of a higher educational establishment to evaluate the level of English language proficiency and to analyze the impact of these tools on the level of foreign language competence of students.
\end{abstract}

Keywords: online assessment; online test; foreign language competence; higher educational establishment.

\section{REFERENCES (TRANSLATED AND TRANSLITERATED)}

[1] T. O. Wolfovska, "Communicative competence of youth as one of the prerequisites for the achievement of a life goal", Shliakh osvity. 2001. N 3. C. 13-16. (in Ukrainian).

[2] Descriptors of Key Competences in the National Qualification Framework// Competences of Personal Development [Online]. Available: http://cpd.yolasite.com/key-competences.php. Accessed on: May 23, 2018. (in English).

[3] L.V. Sazanovych, " The experience of using authentic language textbooks in a medical high school" Naukovi zapysky Natsionalnoho universytetu "Ostrozka akademiia". Seriia : Filolohichna, Vyp. 42. C. 298-300, 2014. [Online]. Available: http://nbuv.gov.ua/UJRN/Nznuoaf_2014_42_91. Accessed on: May 23, 2018. (in Ukrainian).

[4] Generic Competences [Online]. Available: http://www.unideusto.org/tuningeu/competences/generic.html. Accessed on: May 12, 2018. (in English).

[5] D. Lasagabaster, 2008. Foreign language competence in content and language integrated courses. The Open Applied Linguistics Journal, I: 31-42. (in English). 
[6] S. Yu. Nikolaeva, "Fundamentals of modern methods of teaching foreign languages", K .: Lenvit. 285 p., 2008 (in Ukrainian).

[7] N. S. Nikitina, "Using multimedia means in teaching a foreign language of professional orientation in high school" [Online]. Available: http://confesp.fl.kpi.ua/ru/node/1096. Accessed on: May 23, 2018. (in Ukrainian).

[8] C. M. Clarke, \& M. F. Garrett, "Rapid adaptation to foreign-accented English". The Journal of the Acoustical Society of America, 116 (6), 3647-3658, 2004. (in English).

[9] A. M. Pinto-Llorente, M. C. Sánchez-Gómez, F. J. García-Peñalvo, \& S. Casillas Martín, "The use of online quizzes for continuous assessment and self-assessment of second-language learners". In F. J. García-Peñalvo (Ed.), Proceedings of the Fourth International Conference on Technological Ecosystems for Enhancing Multiculturality (TEEM'16) (Salamanca, Spain, November 2-4, 2016) (pp. 819-824). New York, NY, USA: ACM. doi:10.1145/3012430.3012612 (in English).

[10] A Common European Framework of Reference for Languages: Learning, Teaching, Assessment. Cambridge University Press. The Edinburgh Building Shaftesbury Road UK- CB2 2RU Cambridge ROYAUME UNI. 200 p, 2001. [Online]. Available: http://www.cambridge.org/uk. Accessed on: May 30, 2018. (in English).

[11] Cambridge English Aanguage [Online]. Avsessment Available: http://www.cambridgeenglish.org/images/172992-full-level-descriptors-cambridge-english-teachingframework.pdf. Accessed on: May 30, 2018. (in English).

[12] Mayette, Annaliese, "A thematic analysis of experiences of non-native english speaking international graduate students with the internet-based test of english as a foreign language." Dissertation Submitted in Partial Fulfillment of the Requirements for the Degree of Doctor pf Philosophy Educational Linguistics The University of New Mexico Albuquerque, New Mexico, 2014. [Online]. Available: http://digitalrepository.unm.edu/ling_etds/23. Accessed on: May 30, 2018. (in English).

[13] Cathy Lee T. Arcuino, "The relationship between the Test of English as a Foreign Language (TOEFL), the international English Language Testing System (IELTS) scores and academic success of international master's students". In partial fulfillment of the requirements For the Degree of Doctor of Philosophy Colorado State University Fort Collins, Colorado, 2013. [Online]. Available: https://dspace.library.colostate.edu/bitstream/handle/10217/78818/Arcuino_colostate_0053A_11657.pdf? sequence=1. Accessed on: May 12, 2018. (in English).

[14] Roger Hawkey, "Impact Theory and Practice Studies of the IELTS test and Progetto Lingue 2000", 2006 [Online]. Available: http://www.cambridgeenglish.org/images/329230-studies-in-language-testingvolume-24.pdf. Accessed on: May 26, 2018. (in English). 